$\begin{array}{cl}\text { Türkiye Tarımsal Araştırmalar Dergisi } & \text { Turk J Agric Res } \\ \text { dergipark.gov.tr/tutad } & \text { 2017, 4(2): 155-162 } \\ \text { O TÜTAD } & \text { ISSN: 2148-2306 } \\ \text { e-ISSN: 2528-858X } & \text { doi: 10.19159/tutad.293446 }\end{array}$

\title{
Doğal Vejetasyondan Toplanan Bazı Yonca (Medicago sativa L.) Genotiplerinin Ot Verim ve Kalitelerinin Belirlenmesi*
}

\author{
Semih AÇIKBAŞ ${ }^{* * *}$, Sebahattin ALBAYRAK², Mevüt TÜRK ${ }^{3}$ \\ ${ }^{I}$ Siirt Üniversitesi, Ziraat Fakültesi, Tarla Bitkileri Bölümü, Siirt, TÜRKIYE \\ ${ }^{2}$ Ondokuz Mayls Üniversitesi, Bafra Meslek Yüksekokulu, Bitkisel ve Hayvansal Üretim Bölümü, Bafra-Samsun, TÜRKIYYE \\ ${ }^{3}$ Süleyman Demirel Üniversitesi, Ziraat Fakültesi, Tarla Bitkileri Bölümü, Isparta, TÜRKİYE
}

\begin{abstract}
Geliş Tarihi/Received: 22.02 .2017
Kabul Tarihi/Accepted: 19.06 .2017

**Sorumlu Yazar/Corresponding Author: semihacikbas@siirt.edu.tr

Ö zet: Buçalışma; Göller yöresi doğal florasından toplanan yonca (Medicago sativa L.) genotiplerinin ot verimleri ve kalit e özelliklerini belirlemek amacıyla yürütülmüştür. Araştırmada denemeler, tesadüf blokları deneme desenine göre 3 tekerrürlü olarak kurulmuştur. Araştırmanın bitkisel materyalini; 15 adet yonca genotipi ile 2 adet tescilli yonca çeşidi oluşturmuş ve ele alınan genotip ve çeşitler; kuru ot verimi, ham protein (HP) oranı, HP verimi, asit çözücülerde çözünmeyen lif (ADF), nötr çözücülerde çözünmeyen lif (NDF), toplam sindirilebilir besin maddesi (TSBM) ve nispi yem değerleri (NYD) yönünden değerlendirilmiştir. Araştırma sonuçlarına göre; kuru ot verimi yönünden istatistiksel anlamda birinci grubu oluşturan Hüyük-1 (2145 kg da $\left.{ }^{-1}\right)$, Sandıkl1-3 (2137 $\left.\mathrm{kg} \mathrm{da}^{-1}\right)$ ve Yenişarbademli-2 $\left(2183 \mathrm{~kg} \mathrm{da}^{-1}\right)$ yonca genotiplerinin tescilli çeşitlerden daha üstün performans gösterdikleri; Hüyük-1 yonca genotipinden HP oranı ve HP verimi ile ADF, NDF ve TSBM bakımından çok iyi/en üstün kaliteli kuru ot elde edildiği belirlenmiştir. Elde edilen bu bilgiler 1şığında Hüyük-1 yonca genotipinin ıslah çalışmalarında kullanılabileceği sonucuna varılmıştır.
\end{abstract}

Anahtar Kelimeler: Yonca, kuru ot verimi, ham protein oran1, ADF, nispi yem değeri

\section{Determination of Forage Yield and Quality of Some Alfalfa (Medicago sativa L.) Genotypes Collected From Natural Vegetation}

\begin{abstract}
This work; it was conducted in order to determine the herbage yield and quality characteristics of alfalfa (Medicago sativa L.) genotypes collected from natural flora in the 'Göller Bölgesi'. Experiments in the research were set up in 3 replications, according to the design of random blocks. The herbal material of the study; 15 alfalfa genotypes and 2 registered alfalfa varieties; crude protein ratio, crude protein yield, acid detergent fiber (ADF), neutral detergent fiber (NDF), total digestible nutrient (TDN) and relative feed values (RFV). According to the results of the research; Hüyük-1 $\left(2145 \mathrm{~kg} \mathrm{da}^{-1}\right)$, Sandıkl1-3 $\left(2137 \mathrm{~kg} \mathrm{da}^{-1}\right)$ and Yenişarbademli-2 $\left(2183 \mathrm{~kg} \mathrm{da}^{-1}\right)$ alfalfa genotypes, which constitute the first group statistically in terms of dry matter, outperformed registered varieties; it has been determined that the $\mathrm{CP}$ ratio and the CP yield of the Hüyük-1 alfalfa genotype result in excellent / highest quality dry matter in terms of ADF, NDF and TDN. The obtained information is the result of the genotype of the Hüyük-1 alfalfa in the light can be used in breeding studies.
\end{abstract}

Keywords: Alfalfa, dry matter yield, crude protein ratio, ADF, relative feed values

\section{Giriş}

Günümüzde artan nüfusa paralel olarak tarım teknolojisinin gelişmesi, bir yandan tarımsal üretimi ve dolayısıyla birim alandaki verimi artırırken; diğer yandan, özellikle toprak ve su kaynaklarının bilinçsiz şekilde kullanımı doğal kaynaklar üzerindeki baskıyı da arttırmaktadır. Bunun yanı sıra, küresel is ınma ve kuraklık tehdidi nedeniyle değişen ekolojik koşullar, bitkisel gen depolarının kaynağı konumundaki çayır ve mera alanları (Genç Lermi ve Palta, 2014) üzerindeki

\footnotetext{
*: Bu çalışma, Süleyman Demirel Üniversitesi Fen Bilimleri Enstitüsü Yüksek Lisans Tez çalışmasının bir bölümünden üretilmiştir. Çalışma; 15-17 Mayıs 2017 tarihlerinde düzenlenen "The International Conference on Agriculture, Forest, Food Sciences and Technologies (ICAFOF)" isimli uluslar arası kongrede sözlü bildiri olarak sunulmuş olup, özet olarak basılmıștır.
} 
bitki türlerinin gün geçtikçe yok olmasına sebep olmaktadır. Oysaki, artan nüfusun beslenme ihtiyacının karşılanması ancak ve ancak, hem bitkisel ve hem de hayvansal üretim kaynaklarının doğru bir şekilde kullanılması ile mümkün olmaktadır. Günümüzde özellikle bitki biyoteknolojisi ve bitki ıs lahındaki hızlı gelişmeler göz önüne alındığında, doğal kaynakların korunması bu anlamda da büyük önem taşımaktadır.

Hayvancilı işletmelerinin sigortası konumundaki doğal çayır ve mera alanlarının zamansız ve kapasitelerinin üzerinde hayvan sayıs1 ile otlatılmaları sonucunda, söz konusu alanlardaki iyi cins yem bitkisi türlerinin yok olmasına ve dolayısıyla ülkemizin birçok bölgesinde hayvansal üretim için ihtiyaç duyulan kaliteli kaba yem açığının artmasına neden olmuştur. Bu durum, çayır mera alanlarındaki ıs lah çalışmalarına bir an evvel hız verilmesini gerektirdiği gibi; kaba yem açığının kapatılması amacıyla tarla tarımı içerisinde yem bitkileri ekiliş alanının arttırılmasına yönelik çalışmaların da planlı bir şekilde yürütülmesini de gerektirmektedir.

Bugün için ülkemiz yem bitkileri tarımının en önemli sorunları arasinda tohumluk sorunu gelmekte olup, yem bitkileri ekiminde kullanılan tohumluk materyali genellikle yerel popülasyonlardan oluşmaktadır. $\mathrm{Bu}$ durum özellikle, dünyada ve ülkemizde en çok ekiliş miktarına sahip yem bitkisi olan yoncada, küsküt gibi zararlı ot tohumlarıyla bulaşık tohumluğun yaygınlaşmasına neden olmaktadır. $\mathrm{Bu}$ ve benzeri sorunları ortadan kaldırmak için, öncelikle farklı ekolojilerde yetiştirilebilecek farklı tür ve çeşitlerin geliştirilmesi ve sslah edilmesi, adaptasyon ve verim denemelerinin yürütülmesi gerekmektedir. Türkiye doğal florasının yonca türleri bakımından oldukça zengin olduğu, buna karşılık, 1slah edilmiş yonca çeşitlerinin sınırlı sayıda olduğu (Karakurt ve Firıncioğlu, 2003) dikkate alındığında; tarımı yapılan tüm yem bitkileri içerisinde mineral madde ve vitaminler bakımından çok daha zengin ve daha yüksek besleme değerine sahip yonca (Manga ve ark., 1995) bitkisinde ıslah çalışmalarına ağırlık verilmesi, yem bitkileri tarımının geliştirilmesi açısından büyük önem taşımaktadır. Yem bitkileri ıslahının ise ilk basamağının doğal kaynakların değerlendirilmesi (Akgün ve ark., 1998) olduğu unutulmamalıdır.

Doğal florada bulunan gerek tek y1llik ve gerekse çok yıllık yoncaların bazı tarımsal özelliklerinin belirlenmesi; yapilacak islah çalışmalarına önemli bir kaynak teşkil edecek; sslah çalışmaları ile de verimli ve kaliteli ot elde edilecek ve aynı zamanda mera islahında kullanılabilecek genotiplerin ortaya çımmasına imkân sağlayacaktır. Nitekim bu amaçla ülkemizin farklı ekolojilerinde, örneğin; Ankara'da Karakurt ve Frrıncıŏlu (2003), Ege Bölgesi'nde Demiroğlu ve ark. (2008) ve Kavut ve ark. (2015), Erzurum'da Yeşil ve Şengül (2009), Orta Karadeniz Bölgesi'nde Aydın ve ark. (2015), Güneydoğu Anadolu Bölgesi'nde Saruhan ve Kuşvuran (2011), Bartın yöresinde Genç Lermi ve Palta (2014), Batı Akdeniz sahil kuşağında Öten ve Albayrak (2014), Antalya'da Öten ve ark. (2016) tarafindan yapılan çalışmaların bazılarında doğal floradan toplanan yonca popülasyonlarının mera ıslahı ve yem bitkileri yetiştiriciliğindeki potansiyelleri belirlenmiş ve çalşıllan bölgelerde yonca sslahı için zengin genetik kaynakların bulunduğu vurgulanmış; adı geçen bazı çalışmalarda ise, yonca genotiplerinin verim ve morfolojik özellikleri ile adaptasyon kabiliyetleri ortaya konmuştur.

$\mathrm{Bu}$ araştırma; Göller yöresinden toplanan ve klonla çoğaltılan, elde edilen klonların tarlaya şaşırtılarak bazı gözlem ve ölçümler neticesinde üstün nitelik gösteren yonca genotiplerinin, yonca 1slah programına dâhil edilmesine yönelik olarak verim ve bazı kalite kriterlerinin belirlenmesi amacıyla yürütülmüştür.

\section{Materyal ve Yöntem}

Araştırmanın bitkisel materyalini; TÜBITTAK $110 \mathrm{O} 257$ numaralı proje kapsaminda, Göller yöresinden 2010 yılında klon olarak toplanan ve 3 y1l boyunca fenolojik, morfolojik, verim ve kalite analizleri yapılarak, üçüncü yılın sonunda üstün özellik gösteren ve moleküler karakterizasyon bakımından da farklilı arz eden 15 yonca genotipleri (Ağlasun-2, Bucak-3, Eğirdir-2, Gelendost-1, Karaağaç-3, Hüyük-1, Yalvaç-3, Uluborlu-1, Senirkent-2, Sand1kl-3, Bolvadin-1, Bolvadin-3, Yenişar-2, Beyşehir-1 ve Yeşilova-3) oluşturmaktadır. Elde edilen bu genotipler ile birlikte, kıyaslamak amacıyla Bilensoy 80 ve Gea yonca çeşitleri de çalışmaya dâhil edilmiştir.

Araştırmanın tarla denemesi; Süleyman Demirel Üniversitesi, Tarımsal Araştırma ve Uygulama Merkezi arazisinde 2014-2015 yıllarında yürütülmüştür. Deneme kurulmadan önce 0-20 cm derinlikten alınan toprakların bazı fiziksel ve kimyasal analiz sonuçlarına göre deneme alanı topraklarının; tınlı bünyeli, hafif alkalin karakterli $(\mathrm{pH}=7.65)$ ve tuzluluk $(0.044$ mmhos $\mathrm{cm}^{-1}$ ) probleminin olmadığ 1 belirlenmiştir. Toprakların; organik madde içeriğinin ( $\%$ 0.82) çok az, kireç içeriğinin (\% 1.35) kireçli, alınabilir fosfor $\left(\begin{array}{llll}11.5 & \mathrm{~kg} & \mathrm{P}_{2} \mathrm{O}_{5} & \mathrm{da}^{-1}\end{array}\right) \quad$ ve potasyum 


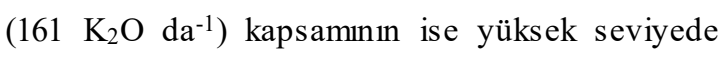
olduğu saptanmıştır.

Araştırma yerinin uzun yıllar ve deneme yıllarına ait bazı iklim verileri Tablo 1'de verilmiştir. Yörede uzun yıllar sicaklık ortalaması $12.2{ }^{\circ} \mathrm{C}$ iken; araştırma yıllarındaki (2014 ve 2015) ortalama sıcaklık değerleri sırasıyla $13.0{ }^{\circ} \mathrm{C}$ ve 13.5 ${ }^{\circ} \mathrm{C}$ olarak gerçekleşmiştir. Araştırma yıllarındaki toplam yağış miktarları sırasıyla 670.8 $\mathrm{mm}$ ve $533.5 \mathrm{~mm}$ olarak gerçekleşmiş olup, uzun yıllar toplam yağ 1 ş ortalaması ise $543.6 \mathrm{~mm}$ olarak kaydedilmiştir. Deneme yılları ile uzun yılların ortalama nispi nem değerleri paralellik göstermiştir (Tablo 1).

Ekimden önce deneme alanı pulluk ile sürülmüş, daha sonra diskaro ve tırmık çekilerek toprak ekime hazır hale getirilmiştir. Tarla denemesi, tesadüf blokları deneme desenine göre 3 tekrarlamalı olarak kurulmuştur. Ekimde sıra arası mesafe $25 \mathrm{~cm}$ olup, her parselde 4 sira olacak şekilde ekim planlanmıştır. Buna göre parsel büyüklüğü $1.00 \mathrm{~m}$ x $2.00 \mathrm{~m}=2.0 \mathrm{~m}^{2}$ olup, dekara $2.0 \mathrm{~kg}$ hesabıyla tohum atılmıstır. Ekimden önce toprak analiz sonuçlarına göre dekara $3 \mathrm{~kg}$ saf azot ve $8 \mathrm{~kg} \mathrm{P}_{2} \mathrm{O}_{5}$ olacak şekilde gübre uygulamas 1 yapılmıştır. Buna göre ekim işlemi 07 Nisan 2014 tarihinde gerçekleştirilmiştir.

Araştırmanın tesis yılında (2014 yılı) herhangi bir değerlendirme yapılmamış, normal biçim ve bakım işlemleri yapılarak yoncalığın gelişimi sağlanmış ve araştırmanın ikinci yılında gerekli ölçüm ve değerlendirmeler gerçekleştirilmiştir.

Hasat işlemi, parsel başlarından 50’şer cm, parsel kenarlarından ise birer sıra kenar tesiri bırakılarak, biçimler \% 10 çiçeklenme (çiçeklenme başlangıcı) döneminde yapılmıştır. Araştırmada yonca genotiplerinden bir sezonda 5 biçim alınmıştır.

Her biçimde biçilen bitkilerin tartımı yapılmış, hasat alanı dikkate alınarak dekara yaş ot verimleri tespit edilmiştir. Yaş ot verimi belirlenen parsellerden $500 \mathrm{~g}$ bitki örneği alınarak; alınan örnekler önce hava kuru ortamda bir süre soldurulduktan sonra, $70{ }^{\circ} \mathrm{C}$ 'ye ayarlı kurutma firınında 48 saat süreyle kurutularak bitkilerin kuru ot oranları belirlenmiştir. Elde edilen kuru ot oranı değerleriyle, yaş ot verimleri oranlanarak çeşitlerin dekara kuru ot verimleri saptanmıştır. Kuru ot verimi amaciyla alınan ve kurutulan bitki örnekleri öğ̈tülerek, elde edilen örneklerde; ham protein (HP) analizi Kacar ve İnal (2008), as it çözücülerde çözünmeyen lif (ADF) ve nötr çözücülerde çözünmeyen lif (NDF) analizleri Van Soest ve ark. (1991) tarafindan bildirilen esaslar dâhilinde yapılmıştır. Ham protein verimleri, ham protein oranlarının kuru ot verimi değerleriyle çarpılmasıyla saptanmıştır. Kuru otun toplam sindirilebilir besin maddesi (TSBM, \%), Moore ve Undersander (2002) tarafindan geliştirilen Eşitlik 1 yardımıyla hesaplanmıştır.

$\operatorname{TSBM}(\%)=82.38-(0.7515 \times \%$ ADF $)$

Nispi yem değeri (NYD)'nin belirlenmesinde ise, Van Dyke ve Anderson (2000) tarafindan geliştirilen aşağıdaki eşitliklerden faydalanılmıştır.

$$
\begin{aligned}
& \text { SKM }(\%)=88.9-(0.779 \times \% \text { ADF }) \\
& \text { KMT }(\%)=120 / \% \text { NDF } \\
& \text { NYD }(\%)=\% \text { SKM x \% KMT x } 0.775
\end{aligned}
$$

Eşitliklerde; SKM, sindirilebilir kuru madde;

\begin{tabular}{|c|c|c|c|c|c|c|c|c|c|}
\hline \multirow[b]{2}{*}{ Aylar } & \multicolumn{3}{|c|}{ Yağış (mm) } & \multicolumn{3}{|c|}{ Sicaklık $\left({ }^{\circ} \mathrm{C}\right)$} & \multicolumn{3}{|c|}{ Nispinem (\%) } \\
\hline & $\begin{array}{l}1950- \\
2014\end{array}$ & 2014 & 2015 & $\begin{array}{l}1950- \\
2014\end{array}$ & 2014 & 2015 & $\begin{array}{l}1950- \\
2014\end{array}$ & 2014 & 2015 \\
\hline Ocak & 76.9 & 61.3 & 125.9 & 1.9 & 3.7 & 2.1 & 73.1 & 76.7 & 73.8 \\
\hline Şubat & 62.6 & 23.4 & 57.7 & 2.9 & 5.2 & 3.4 & 70.4 & 60.8 & 68.5 \\
\hline Mart & 56.0 & 78.6 & 111.6 & 6.1 & 7.3 & 6.7 & 65.4 & 63.3 & 65.2 \\
\hline Nisan & 53.1 & 44.8 & 26.1 & 10.8 & 11.7 & 8.6 & 61.3 & 59.5 & 60.0 \\
\hline Mayis & 54.3 & 107.0 & 41.8 & 15.5 & 15.1 & - & 57.4 & 60.3 & - \\
\hline Haziran & 31.5 & 42.8 & 92.2 & 20.1 & 20.0 & 18.3 & 51.2 & 49.8 & 63.5 \\
\hline Temmuz & 14.5 & 0.8 & 3.0 & 23.5 & 24.5 & 23.7 & 45.4 & 43.5 & 47.6 \\
\hline Ağustos & 10.7 & 10.2 & 43.4 & 23.2 & 24.9 & 23.4 & 46.4 & 44.2 & 53.9 \\
\hline Eylül & 16.9 & 99.2 & 8.2 & 18.6 & 18.4 & 21.4 & 51.9 & 58.6 & 54.2 \\
\hline Ekim & 37.7 & 57.1 & 23.6 & 12.9 & 12.9 & 14.6 & 62.0 & 64.7 & 65.3 \\
\hline Kasim & 46.0 & 37.0 & - & 7.4 & 6.8 & - & 68.5 & 69.2 & - \\
\hline Aralık & 84.3 & 108.6 & - & 3.5 & 6.0 & - & 74.7 & 75.2 & - \\
\hline Toplam & 543.6 & 670.8 & 533.5 & - & - & - & - & - & - \\
\hline Ortalama & - & - & - & 12.2 & 13.0 & 13.5 & 60.64 & 60.48 & 61.33 \\
\hline
\end{tabular}
KMT, kuru madde tüketimini ifade etmektedir.

Tablo 1. Araştırma yerine ait bazı iklim verileri (Anonim, 2016) 
Çalışmada yüzde (\%) ile ifade edilen değerlere varyans analizinden önce Arcsin dönüşümünü uygulanmış ve elde edilen veriler tesadüf blokları deneme desenine göre varyans analizine tabi tutulmuştur. Ortalamalar arasındaki farklılıklar Duncan çoklu karşılaştırma testi ile belirlenmiştir (Yurts ever, 1984).

\section{Bulgular ve Tartış ma}

\subsection{Kuru ot verimi}

Toplam kuru ot verimi bakımından yonca genotipleri arasında istatistiksel olarak çok önemli $(\mathrm{P}<0.01)$ düzeyde farklilıklar bulunmuştur. En

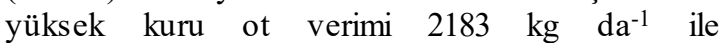
Yenişarbademli-2 yonca genotipinden elde edilmiş olup; Hüyük-1 ve Sand1kl1-3 genotiplerine ait kuru ot verimleri (sırasiyla, 2145 ve $2137 \mathrm{~kg} \mathrm{da}^{-1}$ ) ile aralarındaki farklılığın istatistiksel açıdan önemli olmadığ1 belirlenmiştir. Araştırmada, en düşük kuru ot verimi ise, $1143 \mathrm{~kg} \mathrm{da}^{-1}$ ile Ağlasun-2 genotipinden elde edilmiştir. Araştırma sonuçlarına göre; Göller yöresinden toplanan Yenişarbademli-2, Hüyük-1, Sandıklı-3, Uluborlu1, Bolvadin-1, Bolvadin-3, Beyşehir-1 ve Yeşilova-3 genotipleri, araştırmada kontrol çeşidi olarak kullanılan Bilensoy-80 ve Gea yonca çeşitlerinden kuru ot verimi yönünden daha yüksek performans gösterdikleri görülmektedir (Tablo 2). Güneydoğu Anadolu Bölgesi'nde Saruhan ve Kuşvuran (2011) tarafindan yapılan bir çalışmada, yerel genotipin; Kayseri ve Bilensoy yonca çeşitlerinden daha fazla, Elçi ve SYN-1 yonca çeşitleri ile benzer kuru ot verimi sağladıklarını bildirmiş lerdir.
Farklı yonca genotipleri ile yapılan bazı çalışmalarda kuru ot verimleri; Ege Bölgesi koşullarında 1102-1266 $\mathrm{kg} \quad \mathrm{da}^{-1}$ (Cevheri ve Avcioğlu, 1998) ve 1892-2474 $\mathrm{kg} \mathrm{da}^{-1}$ (Demiroğlu ve ark., 2008), Tokat-Kazova şartlarında 1132$1518 \mathrm{~kg} \mathrm{da}^{-1}$ (Kır, 2010), Karadeniz koşullarında 766-1456 kg da-1 (Töngel ve Ayan, 2010), Van

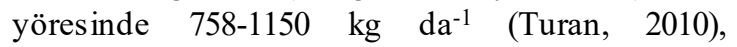
Güneydoğu Anadolu'da 945-1266 $\mathrm{kg} \quad \mathrm{da}^{-1}$ (Saruhan ve Kuşvuran, 2011), Isparta koşullarında 2097-2567 kg da $\mathrm{dY}^{-1}$ (Yılmaz, 2011), Kırşehir koşullarında 454-574 $\mathrm{kg} \mathrm{da}^{-1}$ (İnal, 2015) arasında değişim gösterdiği bildirilmektedir. Araştırmamız sonuçları ile literatürlerdeki bu farklılıklar; ekim zamanı, çeşit ve ekolojik koşulların farklılığından kaynaklandığ 1 düşünülmektedir.

\subsection{Ham protein oranı}

Ham protein oran1 bakımından yonca genotipleri arasinda istatistiksel olarak $\mathrm{P}<0.01$ düzeyinde önemli farklılıklar bulunmuştur. Araştırmada ele alınan genotipler içerisinde, en yüksek HP oran1 (\% 22.6) Hüyük-1 genotipinde belirlenmiştir. Yenişarbademli-2 genotipi ise \% 21.6'llk değeriyle de istatistiki açıdan Hüyük-1 genotipi ile aynı grupta yer almıştır. Gelendost-1 genotipi \% 17.4 ile en düşük HP oranına sahip olmuştur (Tablo 2).

Çalışmada genotiplerin HP oranları \% 17.422.6 arasında değişim göstermiştir (Tablo 2). Yonca ile yapılan birçok çalışmalarda (Manga, 1974, 1981; Horner ve ark., 1985; Miller ve ark., 1991; Akbari ve Avcıŏlu, 1992; Aydın ve ark., 1994; Mustafa ve ark., 2001; Kamalak, 2005;

Tablo 2. Yonca genotiplerinden elde edilen kuru ot verimi, HP oranı, HP verimi, ADF, NDF, TSBM ve NYD sonuçları ${ }^{*}$

\begin{tabular}{|c|c|c|c|c|c|c|c|}
\hline Genotipler & $\begin{array}{c}\text { Kuru ot } \\
\text { verimi }\left(\mathrm{kg} \mathrm{da}^{-1}\right)\end{array}$ & $\begin{array}{c}\text { HP } \\
\text { oran1 }(\%)\end{array}$ & $\begin{array}{c}\mathrm{HP} \\
\text { verimi }\left(\mathrm{kg} \mathrm{da}^{-1}\right)\end{array}$ & $\begin{array}{l}\text { ADF } \\
(\%)\end{array}$ & $\begin{array}{r}\text { NDF } \\
(\%)\end{array}$ & $\begin{array}{c}\text { TSBM } \\
(\%)\end{array}$ & NYD \\
\hline A ğlasun-2 & $1143 \mathrm{j}$ & $18.3 \mathrm{c}-\mathrm{e}$ & 209.71 & $32.4 \mathrm{ab}$ & $42.6 \mathrm{a}$ & $64.1 \mathrm{~d}$ & $138.7 \mathrm{de}$ \\
\hline Bucak-3 & 1308 h1 & $18.3 \mathrm{c}-\mathrm{e}$ & $240.6 \mathrm{~h} 1$ & $28.7 \mathrm{c}$ & $40.1 \mathrm{e}-\mathrm{g}$ & $68.1 \mathrm{a}$ & $154.2 \mathrm{a}$ \\
\hline Eğirdir-2 & 12621 & $18.8 \mathrm{c}-\mathrm{e}$ & $238.2 \mathrm{~h} 1$ & $32.5 \mathrm{ab}$ & $39.5 \mathrm{~g}$ & $64.0 \mathrm{~d}$ & $149.5 \mathrm{~b}$ \\
\hline Gelendost-1 & $1378 \mathrm{gh}$ & $17.4 \mathrm{e}$ & 240.1 h1 & $32.8 \mathrm{a}$ & $40.0 \mathrm{e}-\mathrm{g}$ & $63.7 \mathrm{e}$ & $146.9 \mathrm{bc}$ \\
\hline Şarkikaraağaç-3 & $1492 \mathrm{f}$ & $18.4 \mathrm{c}-\mathrm{e}$ & $275.8 \mathrm{gh}$ & $29.6 \mathrm{c}$ & $41.2 \mathrm{~cd}$ & $67.1 \mathrm{~b}$ & $148.5 \mathrm{~b}$ \\
\hline Hüyük-1 & $2145 \mathrm{a}$ & $22.6 \mathrm{a}$ & $486.9 \mathrm{a}$ & $28.8 \mathrm{c}$ & $40.1 \mathrm{e}-\mathrm{g}$ & $67.9 \mathrm{a}$ & $154.2 \mathrm{a}$ \\
\hline Yalvaç-3 & $1492 \mathrm{f}$ & $18.2 \mathrm{de}$ & 272.9 gh & $29.2 \mathrm{c}$ & $39.8 \mathrm{e}-\mathrm{g}$ & $67.5 \mathrm{ab}$ & $154.4 \mathrm{a}$ \\
\hline Uluborlu-1 & $1875 \mathrm{c}$ & $19.1 \mathrm{c}-\mathrm{e}$ & $360.4 \mathrm{de}$ & $32.9 \mathrm{a}$ & $39.6 \mathrm{gf}$ & $63.6 \mathrm{e}$ & $148.4 \mathrm{~b}$ \\
\hline Senirkent-2 & $1457 \mathrm{fg}$ & $19.9 \mathrm{~b}-\mathrm{d}$ & $291.0 \mathrm{~g}$ & $32.2 \mathrm{ab}$ & $41.4 \mathrm{~b}-\mathrm{d}$ & $64.3 \mathrm{~d}$ & $143.0 \mathrm{~cd}$ \\
\hline Sand1kl1-3 & $2137 \mathrm{a}$ & $20.2 \mathrm{bc}$ & $432.2 \mathrm{~b}$ & $31.4 \mathrm{ab}$ & $40.5 \mathrm{~d}-\mathrm{f}$ & $65.2 \mathrm{c}$ & $147.6 \mathrm{~b}$ \\
\hline Bolvadin-1 & $2045 b$ & $19.8 \mathrm{~b}-\mathrm{d}$ & $405.2 \mathrm{bc}$ & $32.5 \mathrm{ab}$ & $42.5 \mathrm{a}$ & $64.0 \mathrm{~d}$ & $138.9 \mathrm{de}$ \\
\hline Bolvadin-3 & $1914 \mathrm{c}$ & $20.1 \mathrm{~b}-\mathrm{d}$ & $386.0 \mathrm{~cd}$ & $31.1 \mathrm{~b}$ & $42.0 \mathrm{a}-\mathrm{c}$ & $65.5 \mathrm{c}$ & $143.4 \mathrm{~cd}$ \\
\hline Yenişarbademli-2 & $2183 \mathrm{a}$ & $21.6 \mathrm{ab}$ & $473.0 \mathrm{a}$ & $31.9 \mathrm{ab}$ & $40.7 \mathrm{de}$ & $64.6 \mathrm{~d}$ & $146.3 \mathrm{bc}$ \\
\hline Beyşehir-1 & $1917 \mathrm{c}$ & $20.0 \mathrm{~b}-\mathrm{d}$ & $384.8 \mathrm{~cd}$ & $32.9 \mathrm{a}$ & $42.5 \mathrm{a}$ & $63.6 \mathrm{e}$ & $138.2 \mathrm{e}$ \\
\hline Yeşilova-3 & $1970 \mathrm{bc}$ & $20.1 \mathrm{~b}-\mathrm{d}$ & $395.7 \mathrm{~b}-\mathrm{d}$ & $32.3 \mathrm{ab}$ & $42.3 \mathrm{ab}$ & $64.2 \mathrm{~d}$ & $139.9 \mathrm{de}$ \\
\hline Gea (St) & $1721 \mathrm{~d}$ & $19.6 \mathrm{~cd}$ & 338.8 ef & $32.0 \mathrm{ab}$ & $42.2 \mathrm{ab}$ & $64.5 \mathrm{~d}$ & $140.8 \mathrm{de}$ \\
\hline Bilensoy $80(\mathrm{St})$ & $1588 \mathrm{e}$ & $19.3 \mathrm{~cd}$ & $307.3 \mathrm{fg}$ & $32.6 \mathrm{ab}$ & $42.6 \mathrm{a}$ & $63.9 \mathrm{e}$ & $138.1 \mathrm{e}$ \\
\hline Ortalama & 1708 & 19.6 & 324.3 & 31.6 & 41.2 & 65.1 & 145.4 \\
\hline VK (\%) & 3.15 & 4.97 & 6.29 & 2.61 & 1.33 & 1.02 & 1.62 \\
\hline
\end{tabular}

": Aynı sütunda aynı harfle gösterilen ortalamalar arasındaki farklılık istatistiksel açıdan önemli değildir, VK: Varyasyon katsayıSı 
Güngör ve ark., 2008; Katic ve ark., 2009; Saruhan ve Kuşvuran, 2011; Zeinab ve ark., 2013; Geleti ve ark., 2014; İnal, 2015; Yüksel ve ark., 2016; Y1lmaz ve Albayrak, 2016) HP oranının \% 11.429.4 arasında değiştiği rapor edilmiş olup, araştırmamızda elde edilen HP oranlarının literatürlerde bildirilen bu değişim aralı̆̆ içerisinde olduğu görülmüştür. Bununla birlikte, HP oranı bakımından elde edilen verilerin diğer araştırma sonuçlarından farklı olmasının, çeşit ve ekolojik farklılıklardan kaynaklandığ düşünülmektedir.

Rohweder ve ark. (1978) yem değerini HP oranına göre; " $>\%$ 19= En üstün kaliteli, \% 17-19= 1. Kalite (çok iyi), $\% 14-16=2$. Kalite (iyi), $\% 11-$ $13=3$. Kalite (orta), $\% 8-10=4$. Kalite (kötü), $<\% \quad 8=5$. Kalite (kabul edilemez)" olarak sinıflandırmıştır. $\mathrm{Bu}$ sinıflandırmaya göre; HP oranları bakımından, araştırmada incelenen yonca genotipleri kuru otunun "1. Kalite" ve "en üstün kaliteli” olduğu görülmektedir.

\subsection{Ham protein verimi}

Ham protein verimleri bakımından yonca genotipleri arasında istatistiksel olarak \% 1 düzeyinde önemli farklilıklar bulunmuştur. En yüksek HP verimi $486.9 \mathrm{~kg} \mathrm{da} \mathrm{da}^{-1}$ ile Hüyük-1 genotipinden elde edilmiş; Hüyük-1 ve Yenişarbademli-2 genotipleri HP verimi yönünden istatistiksel anlamda aynı grubu oluşturmuştur. Çalışmada en düşük HP verimi $209.7 \mathrm{~kg} \mathrm{da}^{-1}$ ile Ağlasun-2 genotipinden elde edilmiştir (Tablo 2). Ham protein veriminin belirlenmesinde bitkilerin HP oranları ve kuru ot verimi değerleri birlikte değerlendirildiğinden; bu iki özellik yönünden öne çıkan Hüyük-1 ve Yenişarbademli-2 genotipleri yüksek HP verimine sahip olmuşlardır.

Çalışmada yonca genotiplerinde elde edilen HP verimi ile ilgili bulgularımı; Şengül ve Tahtacioğlu (1996)'nun (208.3 $\left.\mathrm{kg} \quad \mathrm{da}^{-1}\right)$, Turan (2010)' 'n (121-185 kg da-1) ve İnal (2015)'in (88.2-112.9 $\mathrm{kg} \mathrm{da}^{-1}$ ) bulgularından yüksek; Manga (1981)'nın Erzurum (307-445 kg $\left.\mathrm{da}^{-1}\right)$, Kır (2010)'in Tokat-Kazova (254.4-332.7 $\left.\mathrm{kg} \quad \mathrm{da}^{-1}\right)$, Avc1 ve ark., (2011)'nın Adana (327.1 kg da-1) ve Y1lmaz ve Albayrak (2016)'ın Isparta (317.4-383.8 $\mathrm{kg} \mathrm{da}^{-1}$ ) koşullarında farklı yonca genotiplerinde belirledikleri HP verimi değerleri ile uyumlu olduğu görülmektedir.

\subsection{Asit çözücülerde çözünmeyen lif (ADF)}

Araştırmada en yüksek ADF oranı \% 32.9 ile Uluborlu-1 ve Beyşehir-1 genotipinden elde edilmiştir. Bununla birlikte Uluborlu-1 ve Beyşehir-1 genotiplerine ait ADF oranı değerleri ile; Ağlasun-2, Eğirdir-2, Gelendost-1,
Senirkent-2, Sandikl1-3, Bolvadin-1 Yenişarbademli-2, Yeşilova-3, Bilensoy-80 ve Gea genotiplerine ait ADF değerleri arasındaki farklılık istatistiksel açıdan önemsiz çıkmıştır. En düşük ADF oranı ise istatistiksel olarak aynı grupta yer alan Bucak-3, Hüyük-1, Yalvaç-3 ve Şarkikaraağaç-3 genotiplerinde (sırasıyla; \% 28.7, 28.8, 29.2 ve 29.6) belirlenmiştir. ADF oranları bakımından yonca genotipleri arasında elde edilen bu farklliklar, istatistiksel olarak $\mathrm{P}<0.01$ düzeyinde önemli bulunmuştur(Tablo 2).

Araştırmada yonca genotiplerinin ADF oranları \% 28.7-32.9 arasında değişiklik göstermiştir (Tablo 2). ADF oranlan ile ilgili elde edilen bu değerler yonca bitkisinde, Horner ve ark. (1985)'nın (\% 35.3), Güngör ve ark. (2008)'nın (\% 32.0-41.6), Katic ve ark. (2009)'nın (\% 37.439.5), Kir (2010)'ı (\% 35.2-36.0) ve İnal (2015)'ın (\% 33.5-36.9) belirledikleri değerlerden düşük; Canbolat ve ark. (2006)'nın (\% 20.20), Kanani ve ark. (2006)'nın (\% 26.5), Geleti ve ark. (2014)'nın (\% 20.7-26.2) bulgularından yüksek; Markovic ve ark. (2008)'nin (\% 16.3- 43.9), Scholtz ve ark. (2009)'nın (\% 21.3-47.2), Y1lmaz ve Albayrak (2016)'in (\% 30.3-35.7) ve Yüksel ve ark. (2016)'nın (\% 31.3-35.2) bulguları ile uyum ve/veya değişim aralığ1 içerisinde olduğu görülmüştür. Çalışmamızda belirlenen ADF oranlarının literatürlerde bildirilen değerler ile arasındaki farklılıkların nedeni; kullanılan çeşit, biçim zamanı ve ekolojik koşulların farklı olması ile açıklanabilir.

Rohweder ve ark. (1978) yem değerini ADF oranına göre; " $<\%$ 31= En üstün kaliteli, \% 31-35= 1. Kalite (çok iyi), $\% 36-40=2$. Kalite (iyi), $\% 41-$ $42=3$. Kalite (orta), \% 43-45=4. Kalite (kötü), $>\% \quad 45=5$. Kalite (kabul edilemez)" olarak sınıflandırmıştır. $\mathrm{Bu}$ sinıflandırmaya göre; ADF oranları bakımından, araştırmada incelenen yonca genotipleri kuru otunun "1. Kalite" ve "en üstün kaliteli” olduğu görülmektedir.

\subsection{Nötr çözücülerde çözünmeyen lif (NDF)}

NDF oranları bakımından yonca genotipleri arasında istatistiksel olarak $\mathrm{P}<0.05$ düzeyinde önemli farklılıklar bulunmuştur. En yüksek NDF oranı \% 42.6 değeriyle istatistiksel olarak aynı grupta yer alan Ağlasun-2 ve Bilensoy-80 genotiplerinden elde edilmiştir. Bununla birlikte bu iki yonca genotipi ile; Bolvadin-1 (\% 42.5), Beyşehir-1 (\% 42.5), Yeşilova-3 (\% 42.3), Gea (\% 42.2) ve Bolvadin-3 (\% 42.0) genotiplerinin ADF oranları arasındaki farklılıklar istatistiksel olarak önemsiz bulunmuştur. Araştırmada, en düşük NDF değeri $\% \quad 39.5$ ile Eğirdir-2 genotipinde belirlenmiştir (Tablo 2). 
Yonca bitkisinde farklı çeşitlerle ve değişik ekolojik koşullarda yapılan çalışmalarda (Horner ve ark., 1985; Markovic ve ark., 2008; Katic ve ark., 2009; Kır, 2010; İnal, 2015; Y1lmaz ve Albayrak, 2016; Yüksel ve ark., 2016) NDF oranlarının \% 42.1 ile \% 56.5 arasında değiştiği belirlenmiş olup, araştırmamız bulgularının bu değerlerden daha düşük olduğu görülmüştür. Buna karşılık; Canbolat ve ark. (2006), Scholtz ve ark. (2009) ve Geleti ve ark. (2014) tarafindan belirlenen değişim aralıklarının (sırasıyla; \% 31.044.7, \% 29.0-65.9 ve \% 36.9-43.5) içerisinde olduğu saptanmıştır. Yoncada bildirilen NDF oranları arasındaki farklılıklar, araştırmalarda kullanılan çeşit farklılıklarından ve çalışmaların yürütüldüğü ekolojik koşullardan kaynaklandığ 1 söylenebilir.

Rohweder ve ark. (1978) yem değerini NDF oranına göre; " $<\% \quad 40=$ En üstün kaliteli, $\% 40-46=$ 1. Kalite (çok iyi), $\% 47-53=2$. Kalite (iyi), $\% 54-$ $60=3$. Kalite (orta), \% 61-65= 4. Kalite (kötü), $>\% 65=5$. Kalite (kabul edilemez)" olarak sinıflandırmıştır. $\mathrm{Bu}$ sinıflandırmaya göre; NDF oranları bakımından, araştırmada incelenen yonca genotipleri kuru otunun "1. Kalite" ve "en üstün kaliteli” olduğu görülmektedir.

\subsection{Toplam sindirilebilir besin maddesi (TSBM)}

Toplam sindirilebilir besin maddesi bakımından yonca genotipleri arasında istatistiksel olarak $\mathrm{P}<0.01$ düzeyinde farklılıklar bulunmuştur. En yüksek TSBM değeri \% 68.09 ile Bucak-3 genotipinde elde edilirken; Bucak-3 genotipi ile Hüyük-1 ve Yalvaç-3 genotiplerinin TSBM değerleri (surasıyla, \% 67.99 ve $\%$ 67.56) arasındaki farklılı istatistiksel açıdan önemsiz çıkmıştır. Çalışmada, en düşük TSBM değerleri istatistiksel olarak aynı grupta yer alan; Bilensoy 80, Gelendost-1, Uluborlu-1 ve Beyşehir-1 genotiplerinden (sirasiyla; \% 63.9, 63.7, 63.6 ve 63.6) elde edilmiştir (Tablo 2).

Bazı araştırmacıların yonca da yaptığı çalışmalarda TSBM değerlerini $\%$ 52.7- 78 arasında olduğunun tespit etmişlerdir (Fox ve ark., 1991; Yolcu ve ark., 2014; Türk ve Özen, 2016). Çalışmada en düşük ve en yüksek istatistiki grubu oluşturan bulgular \% 63.6- 68.09 arasında değişim gösterdiği görülmektedir. Araştırmacıların yapmış olduğu bulgular ile çalışmamızdaki bulguların benzerlik gösterdiği görülmektedir.

\subsection{Nispi yem değeri (NYD)}

Nispi yem değerleri bakımından yonca genotipleri arasinda istatistiksel olarak $\mathrm{P}<0.05$ düzeyinde önemli farklılıklar bulunmuştur. En yüksek nispi yem değerleri istatistiks el açıdan aynı grupta yer alan Yalvaç-3 (154.4), Bucak-3 (154.2) ve Hüyük-1 (154.2) genotiplerinden elde edilmiştir. Çalışmada en düşük nispi yem değerine sahip genotipler ise yine istatistiksel açıdan aynı grupta yer alan Bilensoy-80 (138.1) ve Beyşehir-1 (138.2) yonca genotiplerinde belirlenmiştir (Tablo 2).

Farklı ekolojilerde farklı yonca çeşitleri ile yapılan çalışmalarda nispi yem değerlerini; Yavuz (2005) 118.8, Canbolat ve ark. (2006) 135, Yolcu ve ark. (2008) 104.8-185.0, Geleti ve ark. (2014) 154.0-189.5, Gündel ve ark. (2014) 124.5, Çaçan ve ark. (2015) 126.6 ve İnal (2015) 118.4-125.3 olarak tespit etmiş lerdir.

Rohweder ve ark. (1978) yem değerini nispi yem değerine göre; " $>151=$ En üstün kaliteli, 151$125=1$. Kalite (çok iyi), $124-103=2$. Kalite (iyi), $102-87=3$. Kalite (orta), $86-75=4$. Kalite (kötü), $<75=5$. Kalite (kabul edilemez)" olarak sinıflandırmıştır. $\mathrm{Bu}$ sinıflandırmaya göre; NYD bakımından, araştırmada incelenen yonca genotipleri kuru otunun "1. Kalite" ve "en üstün kaliteli” olduğu görülmektedir.

\section{Sonuçlar}

Göller yöresinden toplanan yonca (Medicago sativa L.) genotiplerinin ot verimi ve bazı kalite özelliklerinin belirlendiği bu araştırmanın sonuçlarına göre; kuru ot verimi bakımından çalışmada ele alınan yonca genotiplerinden Hüyük-1, Sand1kl1-3 ve Yenişarbademli-2 yonca genotiplerinin ön plana çıktığ1 görülmüştür. Araştırmada ele alınan tescilli çeşitler ile kuru otun kalitesi kıyaslandığında; incelenen yonca genotiplerinin ve çeşitlerinin tamamından çok iyi/en üstün kaliteli kuru ot elde edilse de, özellikle ADF ve NDF oranları bakımından Hüyük-1 genotipi tescilli çeşitlerden daha düşük değerlere sahip olmuştur. Buna ek olarak, aynı genotip HP oran1, TSBM ve NYD bakımından da kontrol çeşitlerine göre üstünlük göstermiştir. Elde edilen bu bilgiler 1şı̆̆ında Hüyük-1 yonca genotipinin ıslah çalışmalarında kullanılabileceği sonucuna varılmıştır.

\section{Teşekkür}

Araştırma, TÜBiTAK 2140066 no’lu proje ve Süleyman Demirel Üniversitesi Bilimsel Araştırma Projeleri Yönetim Birimi (Proje No: 4260-YL115) tarafindan desteklenmiştir.

\section{Kaynaklar}

Akbari, N., Avcioğlu, R., 1992. Ege Bölgesine uygun bazı yonca (Medicago sativa L.) çeşitlerinin 
agronomik özellikleri ile yem kaliteleri üzerinde araştırma. Doktora tezi, Ege Üniversitesi Fen Bilimleri Enstitüsü, İzmir.

Akgün, İ., Tosun, M., Sağsöz, S., 1998. Bitkisel gen kaynaklarının önemi ve Erzurum'un bitkisel gen kaynakları yönünden değerlendirilmesi. Doğu Anadolu Tarım Kongresi, 14-18 Eylül, Erzurum, s. 363-372.

Anonim, 2016. Devlet Meteoroloji İşleri Genel Müdürlüğü, Ankara.

Avcı, M., Aktaş, A., Kılıçalp, N., Hatipoğlu, R., 2011. Development of synthetic cultivar of alfalfa (Medicago sativa L.) on the basis of polycross progeny performance in the southern anatolia. Journal of Food, Agriculture \& Environment, 9(2): 404-408.

Aydın, İ., Acar, Z., Erden, İ., 1994. Samsun ekolojik şartlarında yetiştirilen bazı yonca çeşitlerinin kuru ot ve ham protein verimleri üzerinde bir araştırma. Türkiye Tarla Bitkileri Kongresi, 25-29 Nisan, İzmir, s. 27-31.

Aydın, İ., Uzun, F., Algan, D., 2015. Farklı coğrafi lokasyonlardan toplanan baz1 yabani tek y1llik yonca türlerinin verim ve besinsel özellikleri. Anadolu Tartm Bilimleri Dergisi, 30(3): 275-280.

Canbolat, O., Kamalak, A., Özkan, C.O., Erol, A., Şahin, M., Karakas, E., Özköse, E., 2006. Prediction of relative feed value of alfalfa hays harvested at different maturity stages using in vitro gas production. Livestock Research for Rural Development, 18(2): 111-120.

Cevheri, A.C., Avcioğlu, R., 1998. Bornova koşullarında 11 farklı yonca çeşidinin verim ve diğer bazı verim özellikleri üzerinde araștırmalar. Yüksek lisans tezi, Ege Üniversitesi Fen Bilimleri Enstitüsü, İzmir.

Çaçan, E., Aydın, A., Başbağ, M., 2015. Bingöl Üniversitesi Yerleşkesinde yer alan bazı baklagil yem bitkilerine ait kalite özelliklerinin belirlenmesi. Türk Tarım ve Doğa Bilimleri Dergisi, 2(1): 105111.

Demiroğlu, G., Geren, H., Avcıoğlu, R., 2008. Farklı yonca (Medicago sativa L.) genotiplerinin Ege Bölgesi koşullarına adaptasyonu. Ege Üniversitesi Ziraat Fakültesi Dergisi, 45(1): 1-10.

Fox, D., Kirby, D., Lym, R.G., Caton, J., Krabbenhoft, K., 1991. Chemical composition of leafy spurge and alfalfa. Agriculture and Applied Science, 48(6): 7-9.

Geleti, D., Hailemariam, M., Mengistu, A., Tolera, A., 2014. Biomass yield potential and nutritive value of selected alfalfa (Medicago sativa L.) cultivars grown under tepid to cool sub-moist agro-ecology of ethiopia. Journal of Agricultural Research and Development, 4(1): 7-14.

Genç Lermi, A., Palta, Ş., 2014. Bartın ekolojisindeki Medicago polymorpha L.'nin baz1 bitkisel özellikleri üzerine araştırma. Canakkale Onsekiz Mart Üniversitesi Ziraat Fakültesi Dergisi, 2(2): 141-149.

Gündel, F.D., Karadağ, Y., Çınar, S., 2014. Çukurova ekolojik koşullarında bazı sıcak mevsim baklagil yem bitkilerinin verim, kalite ve adaptasyonu üzerine bir araştırma. Gaziosmanpaşa Üniversitesi Ziraat Fakültesi Dergisi, 31(3): 10-19.

Güngör, T., Başalan, M., Aydoğan, G., 2008. Kırıkkale yöresinde üretilen bazı kaba yemlerde basin madde miktarları ve metabolize enerji düzeylerinin belirlenmesi. Ankara Üniversitesi Veteriner Fakültesi Dergisi, 55: 111-115.

Horner, J.L., Bush, L.J., Adams, G.D., Taliaferro, C.M., 1985. Comparative nutritional value of eastern gamagrass and alfalfa hay for dairy cows. Journal of Dairy Science, 68(10): 2615-2620.

İnal, N., 2015. Kırşehir koşullarında bazı yonca (Medicago sativa L.) çeşitlerinin verim ve kalite özelliklerinin belirlenmesi. Yüksek lisans tezi, Ahi Evran Üniversitesi Fen Bilimleri Enstitüsü, Kırşehir.

Kacar, B., İnal, A., 2008. Bitki Analizleri. Nobel Yayın No: 1241, Fen Bilimleri: 63, Nobel Yayın Dağtım Ltd. Şti., Ankara.

Kamalak, A., 2005. Bazı kaba yemlerin gaz üretim parametreleri ve metabolik enerji içerikleri bakımından karşılaştırılması. Kahramanmaraş Sütçü Imam Üniversitesi Fen ve Mühendislik Dergisi, 8(2): 20-30.

Kanani, J., Lukefahr, S.D., Stanko, R.L., 2006. Evaluation of tropical forage legumes (Medicago sativa, Dolichos lablab, Leucaena leucocephala and Desmanthus bicornutus) for growing goats. Small Ruminant Research, 65(1): 1-7.

Karakurt, E., Firıncioğlu, H.K., 2003. Farkl kaynaklardan sağlanan yonca (Medicago sativa L.) populasyonunda bazı önemli özellikler ve özellikler aras1 ilișkiler. Tarla Bitkileri Merkez Araștırma Enstitüsü Dergisi, 12(1-2): 1-9.

Katić, S., Milić, D., Karagić, D., Vasiljević, S., Glamočić, D., Jajić, I., 2009. Variation of protein, cellulose and mineral contents of lucerne as influenced by cultivar and cut. Biotechnology in Animal Husbandry, 25(5-6): 1189-1195.

Kavut, Y.T., Avcioğlu, R., 2015. Yield and quality performances of various alfalfa (Medicago sativa $\mathrm{L}$.) cultivars in different soil textures in a mediterranean environment. Turkish Journal of Field Crops, 20(1): 65-71.

Kır, H., 2010. Tokat-Kazova Şartlarında Bazı yonca çeşitlerinin performanslarının belirlenmesi üzerinde bir araştırma. Yüksek lisans tezi, Gaziosmanpaşa Üniversitesi Fen Bilimleri Enstitüsü, Tokat.

Manga, İ., 1974. Yonca ve Korunga da değişik olgunluk devrelerinde yapılan biçimlerin ot verimine, otun kalitesine ve yedek besin maddelerine etkileri üzerine bir araştırma. Basılmamış doçentlik tezi, Atatürk Üniversitesi, Erzurum.

Manga, İ., 1981. Erzurum ekolojik koşullarında yetișebilen önemli yonca varyetelerinin bazı morfolojik ve biyolojik özellikleri üzerinde araştırmalar. Atatürk Üniversitesi Yayınları No: 577, Ziraat Fakültesi Yayınları No: 261, Araştırma Serisi No: 172, Erzurum. 
Manga, İ., Acar, Z., Ayan, İ., 1995. Baklagil Yembitkileri. Ondokuz Mayıs Üniversitesi Ziraat Fakültesi, Ders Notu No: 7, Samsun.

Marković, J., Radović, J., Lugić, Z., Sokolović, D., 2008. Nutritive value in leaves and stems of lucerne with advanced maturity and a comparison of methods for determination of lignin content. Grassland Science in Europe,13: 480-482.

Miller, P.S., Garrett, W.N., Hinman, N., 1991. Effects of alfalfa maturity on energy utilization by cattle and nutrient digestibility by cattle and sheep. Journal Animal Science, 69(6): 2591-2600.

Moore, J.E., Undersander, D.J., 2002. Relative forage quality: An alternative to relative feed value and quality index. Florida Ruminant Nutrition Symposium, January 10-11, University of Florida, Gainesville, pp. 16-31.

Mustafa, A.F., Christensen, D.A., McKinnon, J.J., 2001. Chemical composition and ruminal degradability of lucerne (Medicago sativa) product. Journal of the Science of Food and Agriculture, 81(15): 1498-1503.

Rohweder, D.A., Barnes, R.F., Jorgensen, N., 1978. Proposed hay grading standards based on laboratory analyses for evaluating quality. Journal of Animal Science, 47(3): 747-759.

Saruhan, V., Kuşvuran, A., 2011. Güneydoğu Anadolu Bölgesi koşullarında bazı yonca (Medicago sativa L.) çeşitleri ve genotiplerinin verim performanslarının belirlenmesi. Ege Üniversitesi Ziraat Fakültesi Dergisi, 48(2): 133-140.

Scholtz, G.D.J., Van Der Merwe, H.J., Tylutki, T.P., 2009. The nutritive value of South African Medicago sativa L. hay. South African Society For Animal Science, 39(1): 179-182.

Şengül, S., Tahtacioğlu, L., 1996. Şark Yoncasında (Medicago sativa L.) ot ve ham protein veriminin belirlenmesi. Türkiye 3. Çayır-Mera ve Yem Bitkileri Kongresi, 17-19 Haziran, Erzurum, s. 615620.

Turan, N., 2010. Baz1 yonca (Medicago sativa L.) çeşitlerinin farklı ekim zamanlarında verim ve verim unsurlarının belirlenmesi üzerinde bir araştırma. Doktora tezi, Van Yüzüncü Y1l Üniversitesi Fen Bilimleri Enstitüsü, Van.

Türk, M., Özen, F., 2016. Ağlasun orman İçi meralarının verim ve kalitesinin belirlenmesi. Süleyman Demirel Üniversitesi Ziraat Fakültesi Dergisi, 11(1) : 82-88.

Töngel, M.Ö., Ayan, İ., 2010. Nutritional contents and yield performances of lucerne (Medicago sativa L.) cultivars in southern black sea shores. Journal of Animal and Veterinary Advances, 9(15): 2067-2073.

Öten, M., Albayrak, S., 2014. Bat1 Akdeniz sahil kuşağında yaygın yonca (Medicago sativa L.) populasyonlarının toplanmasi ve morfolojik karekterizasy onu. Derim, 31(2):79-88.
Öten, M., Çeçen, S., Erdurmuş, C., 2016. Antaly a doğal florasinda bulunan yonca (Medicago sp.) türlerinin toplanması ve morfolojik özelliklerinin belirlenmesi. Tarla Bitkileri Merkez Araştırma Enstitüsü Dergisi, Özel Say1, 25(2): 195-199.

Van Soest, P.J., Robertson, J.B., Lewis, B.A., 1991. Methods for dietary fiber, neutral detergent fiber, and nostarch polysaccharides in relation to animal nutrition. Journal Dairy Science, 74(10): 35833597.

Van Dyke, N.J., Anderson, P.M., 2000. Interpreting a Forage Analysis. Alabama Cooperative Extension, Circular ANR-890.

Yavuz, M., 2005. Baz1 ruminant yemlerinin nispi yem değeri ve in vitro sindirim değerlerinin belirlenmesi. Gaziosmanpaşa Üniversitesi Ziraat Fakültesi Dergisi, 22(1): 97-101.

Yeşil, M., Şengül, S., 2009. Türkiye'nin değişik yörelerinden toplanan Yonca ekotiplerinin bazı morfolojik özelliklerinin belirlenmesi üzerine bir araştırma. Alınteri Zirai Bilimler Dergisi, 16(1): 16.

Yılmaz, M., 2011. Isparta ekolojik koşullarında bazı yonca (Medicago sativa L.) çeşitlerinin ot verim ve kalitelerinin belirlenmesi. Basılmamış Yüksek lisans tezi, Süleyman Demirel Üniversitesi Fen Bilimleri Enstitüsü, Isparta.

Yılmaz, M., Albayrak, S., 2016. Isparta ekolojik koşullarında bazı yonca (Medicago sativa L.) çeşitlerinin ot verim ve kalitelerinin belirlenmesi. Tarla Bitkileri Merkez Araştırma Enstitüsü Dergisi, 25(1): 42-47.

Yolcu, H., Daşçı, M., Tan, M., Çomaklı, B., 2008. Nutrient value of some lucerne cultivars based on chemical composition for livestock. Asian Journal of Chemistry, 20(5): 4110-4116.

Yolcu, H.İ., Okudan, A., Başaran, S., Özen, N., 2014. Küçükbaş hayvanların beslenmesi açısından bazı maki türlerinin besin madde içeriklerini belirlenmesi. II. Ulusal Akdeniz Orman ve Çevre Seтроzуити, 22-24 Ekim, Isparta, s. 129-135.

Yurtsever, N., 1984. Deney sel İstatistik Metotlar. Tarım Orman ve Köyişleri Bakanlığı, Köy Hizmetleri Genel Müdürlüğ̈̈ Yayınları, Genel Yayın No: 121, Teknik Yay in No: 56, Ankara.

Yüksel, O., Albayrak, S., Türk, M., Sevimay, C.S., 2016. Dry matter yields and some quality features of alfalfa (Medicago sativa L.) cultivars under two different locations of Turkey. Süleyman Demirel Üniversitesi Fen Bilimleri Enstitüsü Dergisi, 20(2): 155-160.

Zeinab, A.E.M., Sallam, A.M., Mohamed, N.A., 2013. Evaluating yield and quality of three alfalfa cultivars using laboratory and saline affected soil. Journal of American Science, 9(12): 5-14. 